\title{
Ivermectin and albendazole withdrawal period in goat milk
}

\author{
Período de carência de ivermectina e albendazol em leite de cabras
}

Santos, Patrícia Silva ${ }^{1}$; Cruz, Jurandir Ferreira da ${ }^{2}$; Santos, José Soares dos ${ }^{3}$; Mottin, Vanessa Daniele ${ }^{2}$; Teixeira Neto, Milton Rezende ${ }^{4}$; Souza, Jennifer Figueredo ${ }^{2}$

1. Instituto Federal da Bahia, Itapetinga - BA, Brasil. E-mail: patizootecnia@gmail.com

2. Universidade Estadual do Sudoeste da Bahia, Laboratório de Reprodução de Caprinos e Ovinos, Departamento de Fitotecnia e Zootecnia, Vitória da Conquista - BA, Brasil. E-mail: cruzjurandir@gmail.com,vmottin@yahoo.com.br, laurela4@hotmail.com

3. Universidade Estadual do Sudoeste da Bahia, Laboratório de Química Analítica,

Departamento de química, Vitória da Conquista - BA, Brasil. E-mail: zesoares@uesb.edu.br

4. Faculdade de Tecnologia e Ciências, Curso de Medicina Veterinária, Vitória da Conquista -

BA, Brasil. E-mail: rezendeteixeira@yahoo.com.br

\section{SUMMARY}

Theaimthis study was to determine the excretion profile of albendazole and ivermectin residues in milk from goats submitted to antiparasitic treatment. Twenty-four Brazilianmongrel lactating and pluriparous goats, maintained extensively on native pasture were orally treatedwith albendazole or ivermectin. Milk samples were collected before and after vermifuges application, in the days $0,2,3$ e 4 to albendazole and $0,3,7,14,21,28,35$ and 42 to ivermectin. The vermifuges residues were detected by high performance liquid cromatography with ultravioletdetector. The amount of residues contained in themilk was decreasing in function of time. The mean daily rates of decrease of albendazole residues were $63.34 \%, 40.18$ and $100.0 \%$, from the $2^{\text {nd }}$ to the $4^{\text {th }}$ day, respectively; on the $3^{\text {rd }}$ day after treatment, $50 \%$ of the samples showed concentrations $\geq 47.61$ $\mu \mathrm{g} \cdot \mathrm{mL}^{-1}$, and on the $4^{\text {th }}$ day, no sample had albendazole residue. The amount excreted of ivermectin was similar between the $3^{\text {rd }}$ and $21^{\text {st }}$ day when all samples presented values $\geq$ $51.90 \mu \mathrm{g} \cdot \mathrm{mL}^{-1}$; on the $35^{\text {th }}$ day, $50 \%$ of the samples showed values above of recommended levels, and on the $42^{\text {nd }}$ day, no sample had detectable ivermectin residue.In conclusion, the milk of Brazilian mongrel goats treated orally with albendazole or ivermectin does not contain its respective residues in detectable amounts from the $4^{\text {th }}$ and $42^{\text {nd }}$ days, respectively, after antiparasitic treatment.

keywords: HPLC, goat milk, residues.

\section{RESUMO}

Objetivou-se determinar o perfil de excreção de resíduos de albendazole e ivermectina em leite de cabras submetidas a tratamento antiparasitário. Vinte e quatro cabras sem padrão racial definido (SPRD), lactantes, pluríparas, criadas extensivamente em pastagem nativa foram tratadas com albendazole ou ivermectina, via oral. As amostras de leite foram coletadas antes e após a aplicação dos vermífugos, nos dias $0,1,2,3$ e 4 para Albendazole e $0,3,7,14,21,28,35$ e 42 para ivermectina. Os resíduos dos vermífugos foram determinados por meio de cromatografia líquida de alta eficiência com detector ultravioleta. A quantidade de resíduos presentes no leite foi decrescente em função do tempo. As taxas medias diárias de decréscimo dos resíduos de albendazole foram 63,34\%, 40,18 e $100,0 \%$, do $2^{\circ}$ ao $4^{\circ}$ dia, respectivamente; no $3^{\circ}$ dia após o tratamento, $50 \%$ das amostras apresentaram concentrações $\geq$ 47,61 $\mu$ g.mL-1 e no $4^{\circ}$ dia, nenhuma amostra apresentou resíduo de albendazole. 
Os teores excretados de ivermectina foram similares entre o $3^{\circ}$ e $21^{\circ}$ dia, quando todas as amostras apresentaram valores $\geq 51,90$ $\mu \mathrm{g} . \mathrm{mL}-1$; no $35^{\circ}$ dia, $50 \%$ das amostras apresentavam valores acima nos níveis recomendáveis; no $42^{\circ}$ dia, nenhuma amostra apresentou resíduo detectável de ivermectina. Conclui-se que o leite de cabras SPRD tratadas oralmente com albendazole ou ivermectina não apresenta seus respectivos resíduos em quantidades detectáveis a partir do $4^{\circ}$ e $42^{\circ}$ dias, respectivamente, após tratamento antiparasitário.

Palavras chave: CLAE, leite caprino, resíduos. 


\section{INTRODUCTION}

In developing countries, the use of goat milk has become a useful strategy to combat malnutrition, considering that its high nutritional value contributes with a significant part of the consumption of protein by the lowincome population (Haenlein, 2004; Park et al., 2007). In the semi-arid region of Brazil, goat milk performs an important social role, being common its use as food by many rural families (Ribeiro \& Ribeiro, 2001).

Although the milk production destined to consumption should avoid to the maximum the presence of pharmacological residues that cause risks to human health (Anvisa, 2006), thedrugs administration aimed to endoparasites control in dairy herds is a frequent practice in Brazil. Benzimidazoles residues (Brandon et al., 2002) and ivermectin residues (Turnipseed et al., 2005; Souza et al., 2007) were detected in bovine milk destined tohuman consumption.

Due to the low cost and the possibility of use in lactating females, benzimidazoles have been the most used antiparasitic drugs in the last decades (Dayan, 2003). Fao/Who (1989), alert to the toxic effect of albendazole, including some studies about carcinogenic, genotoxic and teratogenic effects (Lanusse et al., 2009); the European Community and Anvisa established the maximum residue limit of albendazole in milk at $100 \mu \mathrm{g} \mathrm{L}^{-1}$ (EC, 2004; Anvisa, 2012).

Although ivermectin has a high safety margin in antiparasitic treatments (Ayres \& Almeida, 2002), some of its excretion occurs through the mammary gland (Flajs et al., 2005). Although these effects have not been evidenced in pregnant women (Chippaux et al., 1993), the presence of ivermectin residues in milk may have mutagenic and/or teratogenic effects in some mammalian species (Ema, 2004). The Codex Alimentarius established the maximum residue limit of ivermectin in milk at $10 \mu \mathrm{g} \mathrm{L}^{-1}$ (Fao/Who, 1993).

Considering that information about excretion of antiparasitic drugs through goat milk is scarce and that goat milk is a food commonly used to human consumption, this study aimed to determine the excretion profile of albendazole and ivermectin residues in goat milk submitted to antiparasitic treatment.

\section{MATERIALS AND METHODS}

\section{Animals and colleting samples}

This study was approved by the Ethics Committee on the Use of Animals of the State University of Southwest of Bahia, with protocol $\mathrm{n}^{\mathrm{o}}$. 162/2018.

Twenty-four Brazilian mongrel lactating and pluriparous goats were used in this study, of which 12 were dewormed with albendazole (Aldazol Oral ${ }^{\circledR}$, Vallée, Brazil) at a dose of 7.5 $\mathrm{mg} \mathrm{kg}{ }^{-1}$ of body weight and others 12 goats were dewormed with ivermectin (Ivomec Oral®, Merial, Brazil) at a dose of $200 \mu \mathrm{g} / \mathrm{kg}$ body weight, as suggested by the manufacturers.

The milk samples were collected before and after vermifuges application in the days $\mathrm{D}_{0}, \mathrm{D}_{1}, \mathrm{D}_{2}, \mathrm{D}_{3}$, and $\mathrm{D}_{4}$ to Albendazole and $\mathrm{D}_{0}, \mathrm{D}_{3}, \mathrm{D}_{7}, \mathrm{D}_{14}, \mathrm{D}_{21}$, $\mathrm{D}_{28}, \mathrm{D}_{35}$ and $\mathrm{D}_{42}$ to ivermectin. $\mathrm{D}_{0}$ was the day of vermifuges application.The days and the collecting period were defined according to the time of drug metabolism, described in previous studies, and according to the withdrawal period established by the manufacturers.The samples were conditioned in disposable plastic bags identified and kept frozen in the freezer $\left(-20^{\circ} \mathrm{C}\right)$ until the moment of analysis at Laboratory of Analytical Chemistry of 
UESB to determine the administered vermifuges residues.

\section{Chromatographic analysis}

The reference analytical solutions were prepared by successive dilutions of albendazole standard (Albendazole ${ }^{\circledR}$, Fluka, Sigma-Aldrich, USA) and ivermectin standard (Ivermectin®, Sigma-Aldrich, USA) in ultrapure water obtained from Millipure purification system (Millipore, São Paulo, SP, Brazil).Initially, two stock solutions were prepared. First, $100 \mathrm{~mL}$ stock solution with a concentration of 1000 $\mathrm{mg} \mathrm{L}^{-1}$ of albendazole standard, and another $100 \mathrm{~mL}$ stock solution with a concentration of $500 \mathrm{mg} \mathrm{L}^{-1}$ of ivermectin standard. Then, these solutions were stored in decontaminated polypropylene flasks (Company, Rochester, NY, USA).From the stock solution, the working solutions were prepared in suitable concentrations to the construction of the analytical curves.As a diluent, was used a solution of HPLC grademethanol (Methyl alcohol Isocratic UV-IR-HPLC) and chloroform (Chloroform UV/HPLC spectroscopy, Vetec, Brazil) at ratio 30:70 v/v, respectively, according suggested by Waldia et al. (2008). The working solutions were always prepared on the day of analysis and discarded at the end of the routine.

The mobile phase was prepared by the addition of HPLC grade acetonitrile (isocratic UV-IR-HPLC, Panreac, Spain), Milli-Q water and methanol in the proportion 60:10:30 (v/v/v), respectively (Waldia et al., 2008).

After samples thawing, an aliquot of 2 $\mathrm{mL}$ of milk was transferred to a test tube, and $2 \mathrm{~mL}$ of acetonitrile was added, then centrifuged at $1350 \mathrm{ppm}$ for 5 minutes to obtain the extract.

The extraction procedure of albendazole and ivermectin from the milk samples was performed in four steps: i) activation of extraction cartridges in solid phase - silica-C18 19\% carbon (500 mg.3 mL $\mathrm{mL}^{-1}$, ii) adsorption of albendazole or ivermectin to the sorbent, iii) albendazole or ivermectin elution, and iv) cartridge washing.

For the cartridge activation were used 3 $\mathrm{mL}$ of acetone and $2 \mathrm{~mL}$ of acetonitrile with vacuum application to reach a flow of $3 \mathrm{~mL} \cdot \mathrm{min}^{-1}$. Posteriorly, for adsorption of albendazole or ivermectin to the sorbent, $2 \mathrm{~mL}$ of extract was added to the column with vacuum application as described above. For albendazole elution were used $3 \mathrm{ml}$ of acetonitrile and for ivermectin elution, 3 $\mathrm{ml}$ of acetone were used.The obtained sample was reconstituted with $2 \mathrm{~mL}$ of a solution composed by acetonitrile

/water/methanol 60:10:30 (v/ v / v) in a volumetric flask of $5 \mathrm{~mL}$ and filtered with a $0.22 \mu \mathrm{m}$ syringe filter. After elution, the column was vacuum washed twice, using in the first wash $4 \mathrm{~mL}$ of acetonitrile for three minutes and in the second, $6 \mathrm{~mL}$ of hexane for two minutes.

The albendazole or ivermectin detection was performed by high-performance liquid chromatography with 200 series pump, sampling valve, $20 \mu \mathrm{L}$ loop and UV / Vis detector (HPLC, Perkin Elmer, USA).

For chromatographic separation of albendazole or ivermectin was used a column of $250 \times 4.5 \mathrm{~mm}, 5 \mu \mathrm{m}$ particle size (RP-C18, Thermo, USA). Each sample injected in triplicate $(20 \mu \mathrm{L})$ was submitted to an isocratic elution (flow of $1.8 \mathrm{~mL} \cdot \mathrm{min}^{-1}$ ). The albendazole or ivermectin detection was performed at a temperature of $30{ }^{\circ} \mathrm{C}$ using a wavelength of $245 \mathrm{~nm}$.

The validation procedures of analysis method were performed based on the linearity parameters, accuracy (recovery), precision (repeatability and partial reproducibility), detection limit and quantification. 


\section{Statistical analysis}

The quantitative data obtained from the albendazole concentration on the different days of collection were submitted to analysis of variance (ANOVA) and the means compared by the Tukey test (SAS, version 8.0).Differences were considered significant at $\mathrm{P}<0.05$. To determine the analytical curves and concentration of the albendazole or ivermectin residues were used linear regressions with $\mathrm{P}$ $<0.01$ (SAS, version 8.0).

\section{RESULTS AND DISCUSSION}

The analytical curves by standardization of albendazole or ivermectin presented linearity with determination coefficients of 0.996 and 0.997 , respectively. These coefficients are equal or higher than those established by the Codex Alimentarius (Fao / Who, 1993), Anvisa (2003) and Inmetro (2010), which recommend coefficients $\geq 0.995 ; 0.980$ and $>0.90, \quad$ respectively.Linearity corresponds to the capacity of the method to provide results directly proportional to the substance concentration in test, within a determined range of application.
In similar studies with bovine milk samples containing benzimidazole residues were found determination coefficients of $0.992 ; 0.994$ and 0.999 using system with electrospray ionization with mass detector - HPLC EI-MS (Xi et al., 2010);HPLC system with mass detector-HPLC/MS (Moreno et al., 2005) and HPLC coupled to a detection system with diode array HPLC/UV (Ruyck et al., 2000), respectively. The determination coefficient with the same value $(\mathrm{R} 2=$ 0.999) was obtained in bovine milk samples containing eprinomectin residue using HPLC with fluorescence detector (HPLC-FL) (Pollmeier et al., 2002). Thus, the determination coefficients obtained in the present study demonstrate that the HPLC/UVVis system is suitable for quantification of albendazole and ivermectin residues in goat milk.

The retention times of albendazole in the standard solution and in the samples were 2.16 and 2.17 minutes, respectively. While the retention times of ivermectin were 4.45 and 4.40 , in the same order.In both cases the peaks presented satisfactory resolution, separated from the interfering peaks and there was concordance between the response intensity curves and retention time (Figure 1). 
Figure 1. Chromatograms obtained with the standard solution of albendazole $\left(A_{1}\right)$ or ivermectin $\left(B_{1}\right)$ and with goat milk samples containing albendazole $\left(A_{2}\right)$ or ivermectin $\left(B_{2}\right)$ residues with respective retention times $(R T)$.
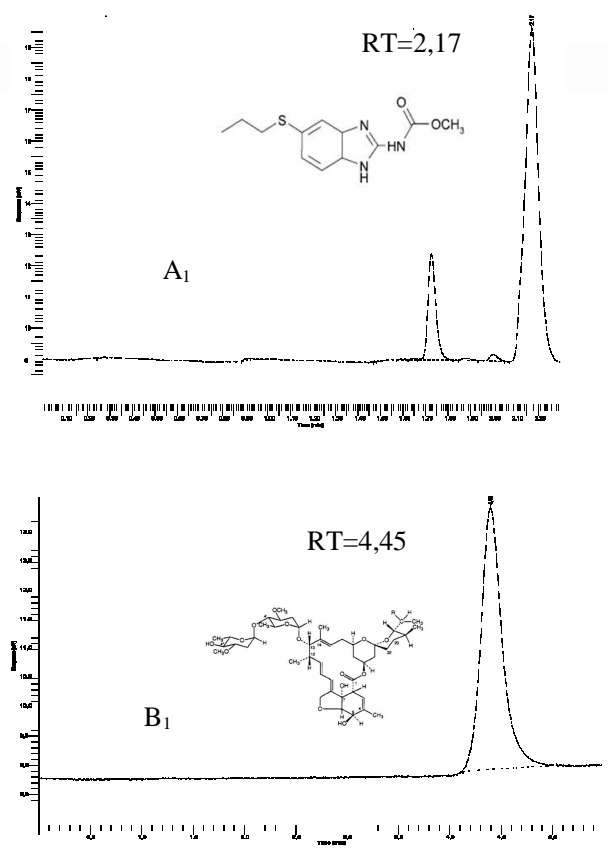

In fortified samples of bovine milk were observed albendazole retention time of 5.86 minutes using HPLC/MS (Whelan et al., 2010) and ivermectin retention time of 6.9 and 11.2 minutes using HPLC-FL (Flajs et al. , 2005; Souza et al., 2007). Even though these times were greater than those found in the present study, it is emphasized that the methodologies used were different, including the fact that the vermifuges were added to milk samples from untreated animals. Considering the retention time as the time spent from the moment of sample injection to the maximum peak observed in the chromatographic system. Thus, the internal temperature of the column, the mobile phase used or even the injection
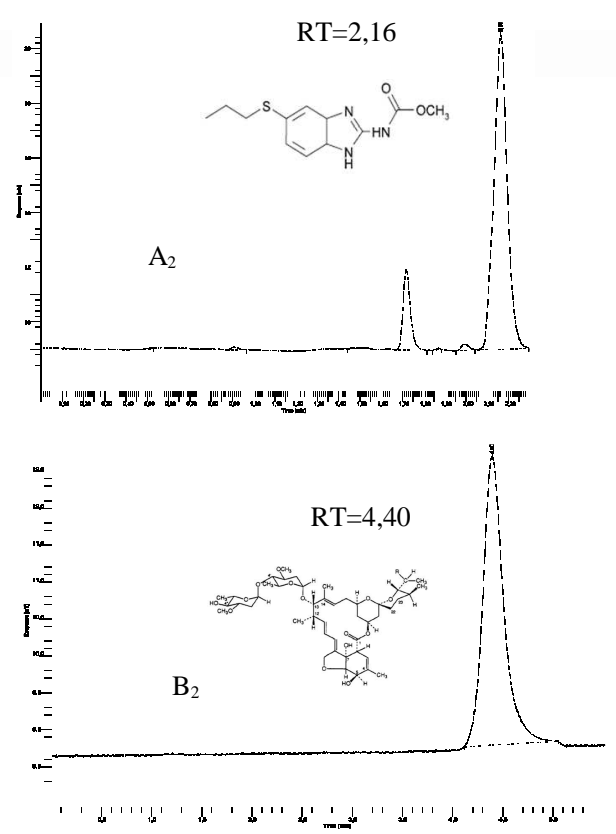

method can influence the retention time of the evaluated residue.

In all samples containing albendazole at different concentration levels $(10,120$ or $480 \mu \mathrm{g} \cdot \mathrm{mL}^{-1}$ ) the mean rate of residue recovery was $88.5 \%$ and the mean values of repeatability and partial reproducibility were $16.9 \%$ and $16.2 \%$, respectively.Similarly, in samples containing ivermectin at concentrations of 10,40 and $320 \mu \mathrm{g} . \mathrm{mL}-1$, the mean recovery residue rate was $92.5 \%$ and the mean values of repeatability and partial reproducibility were $16.1 \%$ and $16.8 \%$, in the same order (Table 1). 
Table 1. Recovery rates, repeatability and partial reproducibility of analytical method used to the analyte albendazole or ivermectin detection in goat milk ${ }^{1}$

\begin{tabular}{llll}
\hline $\begin{array}{l}\text { Concentration } \\
\left(\boldsymbol{\mu g} \cdot \mathbf{m L}^{-\mathbf{1}}\right)\end{array}$ & $\begin{array}{l}\text { Recovery } \\
(\boldsymbol{\%})\end{array}$ & $\begin{array}{l}\text { Repeatability } \\
(\mathbf{\%})^{\mathbf{2}}\end{array}$ & $\begin{array}{l}\text { Partial } \\
\text { reproducibility } \\
(\boldsymbol{\%})^{\mathbf{2}}\end{array}$ \\
\hline Albendazole & & & \\
10 & 85,5 & 14,8 & 16,3 \\
120 & 89,4 & 17,3 & 16,8 \\
480 & 90,6 & 18,6 & 15,6 \\
Ivermectin & & & \\
10 & 95,5 & 16,8 & 14,5 \\
40 & 87,8 & 12,6 & 18,7 \\
320 & 94,2 & 18,9 & 17,2 \\
\hline
\end{tabular}

${ }^{1}$ Added standard solution of albendazole or ivermectin; ${ }^{2}$ Values expressed in relative standard deviation.

In previous studies was observed variation in the recovery residues rates in bovine milk, with rates ranging from $68 \%$ to $85 \%$ for albendazole residues (Ruyck et al., 2000), 77.0 and 97\% (Moreno et al., 2005) and $80.5 \%$ and $101.3 \%$ (Xi et al., 2010).For ivermectin residues were obtained mean recovery rates of $78.8 \%$ (Alvinerie et al., 1994), $\geq$ $60.0 \%$ (Turnipseed et al., 2005) and $\geq 84.0 \%$ (Souza et al. , 2007).

Analyzing these previous studies together with the present results is plausible to admit that the recovery rate of albendazole residues and macrocyclic lactones may be influenced by the matrix and/or the method used. According to Anvisa (2003) the recovery rate should be close to $100 \%$, but if recovery is accurate and exact, smaller values are allowed.

In bovine milk matrix, partial reproducibility values $\leq 14 \%$ were obtained for the analyte albendazole (Xi et al., 2010).In ivermectin residue study, also in bovine milk matrix, repeatability values $\leq 14.7 \%$ and partial reproducibility $\leq 22 \%$ were obtained (Souza et al., 2007).Although the repeatability and partial reproducibility values should not exceed $15 \%$, the maximum acceptable values should be defined according to the matrix, methodology, analyte concentration and the purpose of the method (Anvisa, 2003).

In the present study, the detection limits and quantification of albendazole were 10 and $120 \mu \mathrm{g} \cdot \mathrm{mL}^{-1}$ and ivermectin 10 and $280 \mu \mathrm{g} \cdot \mathrm{mL}^{-1}$, respectively.In bovine milk, detection and quantification limits of the method of $0,01-0,5 \mu \mathrm{g} . \mathrm{L}^{-1}$ and of $0,1-1,0 \mu \mathrm{g} . \mathrm{L}^{-1}$, respectively (Xi et al., 2010) and 3.8 and 6.9 ng.mL ${ }^{-1}$ (Ruyck et al., 2000). For avermectins using HPLC-FL, detection and quantification limits of 5 and $10 \mu \mathrm{g} . \mathrm{L}^{-1}$ (Souza et al., 2007), respectively, were found.

The expressive values of precision (repeatability and partial reproducibility) found in the different concentrations of analyte, in addition to the recovery rate and the detection and quantification limits reinforce the reliability of the analytical method for residue determination of albendazole and ivermectin in goat milk.

The highest concentrations of albendazole were observed in the first 24 hours $\left(101.20+37.4 \mu \mathrm{g} \cdot \mathrm{mL}^{-1}\right)$, and residue was detected in all samples evaluated up to 48 hours after drug administration; the amount of excreted 
residue 24 hours after albendazole administration allowed the formation of two groups, $50 \%$ showed a mean concentration of $68.01 \pm 13.37 \mu \mathrm{g} \cdot \mathrm{mL}^{-1}$ and $50 \% \quad 134.36 \pm 16.04 \mu \mathrm{g} . \mathrm{mL}^{-}$ ${ }^{1}$.However, although a significant difference between the animals about the amount excreted in the first 24 hours (range of $111.56 \mu \mathrm{g} \cdot \mathrm{mL}^{-1}$ ), it was verified that albendazole excretion in the period between 48 and 72 hours occurred the way relatively standardized; from the group with the highest excretion volume, $66.7 \%$ of the goats kept this profile in relation to the others, in the time of 48 hours, however, $33.3 \%$ drastically reduced the amount excreted, revealing the influence of individuality on the metabolism and albendazole excretion. Seventy two hours after albendazole administration, in $50 \%$ of the samples was not detected, but in the other samples were detected concentrations $\geq 47.61 \mu \mathrm{g} \cdot \mathrm{mL}^{-1}$. Ninety six hours after albendazole administration, no residue was detected in the milk.

The excretion time of albendazole in milk is variable in small and large ruminants. The maximum concentrations in bovine milk of oxfendazole, fenbendazole and albendazole were obtained $12 \mathrm{~h}, 24-36$ $\mathrm{h}$ and $12 \mathrm{~h}$, respectively, post administration (Moreno et al., 2005), with values of $<100 \mu \mathrm{g} . \mathrm{L}^{-1}$ of albendazole $48 \mathrm{~h}$ post-treatment (Chu et al., 1993).

The drug metabolism seems to be influenced by the chemical structure of the molecule and the administration route. The concentrations of oxfendazole and albendazole residues are higher in bovine milk when administered orally than subcutaneously (Moreno et al., 2005);it should be noted that the doses are different when applied by different routes, being $5.0 \mathrm{mg} \cdot \mathrm{kg}^{-1}$ by oral route and $3.0 \mathrm{mg} \cdot \mathrm{kg}^{-1}$ by subcutaneous route.

In a previous study, it was observed that 72 hours post drug application the concentration reached an average value lower than $100 \mu \mathrm{g} . \mathrm{L}^{-1}$ in goat and sheep milk (Cinquina et al., 1996). In the present study, the time required for residual values to be $<100 \mu$ g.L-1 was 48 hours, suggesting that Brazilian mongrel goats can metabolize albendazole more rapidly than dairy goats and dairy sheep. On the other hand, there seems to be influence of the individuality in the excretion profile of metabolite, having already been reported in a previous study using fenbendazole (Brandon et al., 2002). In the present study, the expressive variation among individuals can be attributed to the genetic diversity of Brazilian mongrel goats.

In the period between day 3 and day 21 the mean concentrations of ivermectin were similar $(\mathrm{P}>0.05)$, when all samples had values $\geq 51.90 \mu \mathrm{g} . \mathrm{mL}^{-1}$; the mean concentration in the $\mathrm{D}_{28}$ was lower than those observed in previous days $(\mathrm{P}<0.05)$.In the period between $\mathrm{D}_{28}$ and $\mathrm{D}_{42}$ the mean concentrations of ivermectin decreased gradually, being that in the $\mathrm{D}_{28}, 66.6 \%$ presented values $\geq 51.40 \mu \mathrm{g} . \mathrm{mL}^{-1}$ and $33.3 \%$ presented values $<10 \mu \mathrm{g} . \mathrm{mL}^{-1}$; in the $\mathrm{D}_{35}, 50 \%$ of the samples showed concentrations $\geq 45.93 \mu \mathrm{g} \mathrm{mL}^{-1}$, whereas, in the $\mathrm{D}_{42}$, no ivermectin residue was detected in any sample. The highest ivermectin concentration was observed in one animal in the $\mathrm{D}_{3}\left(86.30 \mu \mathrm{g} \mathrm{mL}^{-1}\right)$, and the same animal presented values similar to the others in the period between $\mathrm{D}_{7}$ and $\mathrm{D}_{21}$. Contrarily, the animal that showed the second highest concentration in the $\mathrm{D}_{3}\left(73.82 \mu \mathrm{g} \mathrm{mL} \mathrm{mL}^{-1}\right)$ remained at higher concentrations until $\mathrm{D}_{21}$, when it presented a similar value to the others. 
The fluctuation of ivermectin concentrations in function of time can be a consequence of individual variations in milk synthesis and secretion processes (Cerkvenik et al., 2002).These differences can be attributed to differences in drug absorption rate, metabolic condition and animal body composition (Flajs et al., 2005).Considering that ivermectin fraction eliminated through milk can also be influenced by its fat content (Lanusse et al., 2009), the genetic diversity of the Brazilian mongrerl goats can be an additional factor to be considered in the individual differences observed in the present study.

Although the individual metabolism caused dispersion of the excretion values at the initial moment, was observed that the animals trended to have an excretion pattern of residue in the period between D7 and D21.The samples amplitudes in the $\mathrm{D}_{3}, \mathrm{D}_{7}, \mathrm{D}_{14}$ and $\mathrm{D}_{21}$ were $32.15 ; 14.8 ; 9.10$ and 5.02 $\mu \mathrm{g} . \mathrm{mL}^{-1}$, respectively. This trend of standardization of excretion profile was also verified in the animals that remained excreting ivermectin on days 28 and 35, whose amplitudes were 2.92 and $1.70 \mu \mathrm{g} \cdot \mathrm{mL}^{-1}$, respectively.

When comparing the results obtained with the two drenchs, it was possible to verify that the excretion of albendazole and ivermectin in the milk occurred in a differentiated way. While albendazole excretion occurred in high percentages in the first two days, ivermectin was excreted in small proportion in the first 21 days. The decrease rates of albendazole residue at intervals of 2448 hours; 48-72 hours; 72-96 hours after drug application were $63.34 \% ; 40.18 \%$ and $100.0 \%$, respectively.In the ivermectin case, the decrease rates in the intervals $\mathrm{D}_{3}-\mathrm{D}_{7} ; \mathrm{D}_{7}-\mathrm{D}_{14} ; \mathrm{D}_{14}-\mathrm{D}_{21}$; $\mathrm{D}_{21}-\mathrm{D}_{28} ; \mathrm{D}_{28}-\mathrm{D}_{35} ; \mathrm{D}_{35}-\mathrm{D}_{42}$ were $8.7 \%$; $2.1 \% ; 2.6 \%, 34.3 \%, 33.2 \%$ and $100 \%$ respectively (Figure 2).

Figure 2. Concentration curves of albendazole and ivermectin residues in milk of reated native goats.

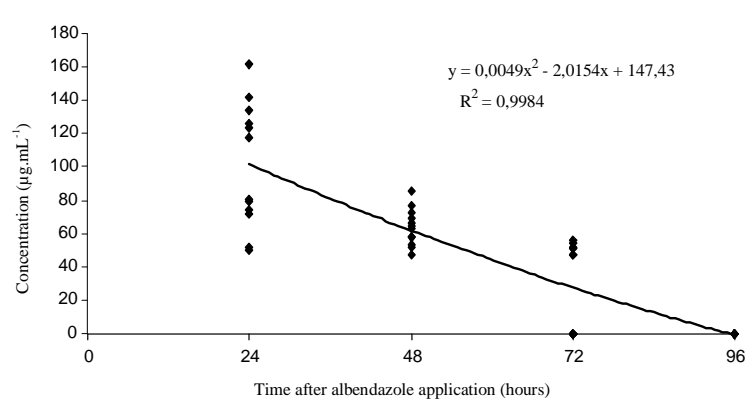

Albendazole rapidly undergoes extensive first-pass metabolism in the liver, being transformed into albendazole sulfoxide, the primary metabolite with antihelmintic activity; Albendazole sulfoxide is mainly eliminated in bile, with a small proportion eliminated by urine and its

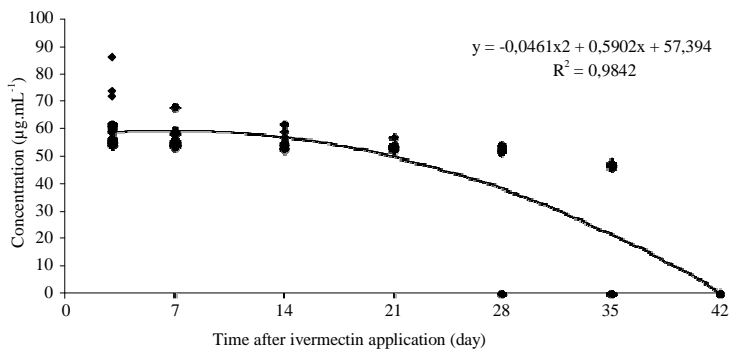

plasma half-life is 8.5 hours (Marques et al., 2002). The amount and excretion time of albendazole by urine varies with species; in cow, $47 \%$ of the administered dose was excreted within 72 hours; in sheep, $51 \%$ of the dose was excreted in 120 hours and in pork, $75 \%$ of the dose was excreted in 48 hours 
(Fao / Who, 1989). Ivermectin has low metabolism, with the most dose being excreted unchanged in feces (90\%), urine $(2 \%)$ and by mammary glands (5$8 \%$ ), with a plasma half-life of 22-28 hours; the ivermectin persistence by a long time in the organism is due to its low plasma clearance, high affinity for lipoproteins and accumulation in adipose tissue (Canga et al., 2009).

Thus, milk of Brazilian mongrel goats treated orally with albendazole or ivermectin does not present their respective residues in detectable amounts from the $4^{\text {th }}$ and $42^{\text {nd }}$ days, respectively, after antiparasitic treatment.

\section{ACKNOWLEDGMENT}

To the owners of Fazenda Várzea Comprida for the infrastructure and animals; FAPESB for financial support.

\section{REFERÊNCIAS}

ALVINERIE, M.; SUTRA, J.F.; GALTIER, P.; TOUTAIN, P.L. Microdose d'ivermectine chez La vache laitiere: concentrations plasmatiques et residus dan lê lait. Revue Medicine Veterinare, v. 169, p. 259-261, 1994.

ANVISA. Agência Nacional de Vigilância Sanitária, Resolução 899, Validação de métodos analíticos e bioanalíticos, Brasília, 2003.

ANVISA. Agência Nacional de Vigilância Sanitária, Resolução RDC N ${ }^{\circ}$ 53, de 2 de outubro de 2012.

Metodologias Analíticas, Ingestão Diária Admissível e Limites Máximos de Resíduos para Medicamentos Veterinários em Alimentos de Origem Animal. Brasília, 2012.
ANVISA. Agência Nacional de Vigilância Sanitária. Programa de Análise de Resíduos de Medicamentos Veterinários em Alimentos de origem animal - PAMVet. Relatório 2004/2005: monitoramento de resíduo em leite exposto ao consumo. 2006. 46p. Disponível em: http://www.Anvisa.gov.br/alimentos/pa mvet/relat\%F3rio_leite_2004-05.pdf. Acesso em: 05/03/2017.

AYRES, M.C.C.; ALMEIDA, M.A.O. Agentes antinematódeos. In: SPINOSA, H. S.; GORNIAK, S. L.; BERNARDI, M. M. Farmacologia aplicada à medicina veterinária. $3^{\mathrm{a}} \mathrm{ed}$. Rio de Janeiro: Guanabara Koogan, 2002. p. 460-463.

BARKER, S. A.; KAPPEL, L. C. Drug residues in milk from cows administered fenbendazole as a paste, drench, or feed top-dressing. Journal of Veterinary Pharmacolology and Therapeutics, v. 20, p. 160-162, 1997.

BRANDON, D. L.; BATES, A.H.; BINDER, R.G.; MONTAQUE, W.C.JR.;WHITEHAND, L.C.; BARKER, S.A. Analysis of fenbendazole residues in bovine milk by ELISA.Journal of Agricultural and Food Chemistry,v. 50, p. 5791-6, 2002.

CANGA, A.G.; PRIETO, A.M.S.; LIÉBANA, M.J.D.; MARTÍNEZ, M.F.; VEGA, M.S.; VIEITEZ, J.J.G. The pharmacokinetics and metabolism of ivermectin in domestic animal species. The Veterinary Journal, v.179, p.2537,2009 .

CERKVENICK, V. CERKVENIK, V.; GRABNAR, V.; SKUBIC, V.; DOGANOC, D.Z.; BEEK, W.M.J.; KEUKENS, H.J.; KOSOROK, M.D.; POGACNIK, M. Ivermectin pharmacokinetics in lactating sheep. 
Veterinary Parasitology,v.104, p. 175185, 2002.

CHIPPAUX, J.; GARDON-WENDEL, N.;GARDON, J.; ERNOULD, J.

Absence ofany adverse effect ofinadvertent ivermectin treatmentduring pregnancy.

Transactions of the Royal Society of Tropical Medicine and Hygiene, v.87, n.3, p.318, 1993.

CHU, P. S.;WANG, R.Y.; BRANDT, T.A.; WEERASINGHE, C.A.

Determination of albendazole-2aminosulfone in bovine milk using high-performance liquid chromatography with fluorometric detection. Journal of chromatography, v.620, n.1, p.129135, 1993.

CINQUINA, A.L.; LONGO, F.; RAPONI, A.; FAGIOLO, A.;CIVITAREALE, C.; BRAMBILLA, G.; COZZANI, R. In: HAAGSMA, N.; RUITER, A. EuroResidue III Conference on Residues of Veterinary Drugs in Food, 1996, Veldhoven, The Netherlands. Proceedings... Faculty of Veterinary Medicine, University of Utrecht, Utrecht, The Netherlands, 1996, p. 331.

DAYAN, A. D. Albendazole, Mebendazole and Praziquantel. Review of Non-Clinical Toxicity and Pharmacokinetics. Acta Tropica, v. 86, p.141-159, 2003.

RUYCK, H.; VAN RENTERGHEM, R.; DE RIDDER, H.; DE BRABANDER, D. Determination of anthelmintic residues in milk by high performance liquid chromatography. Food Control, v. 11, n.3, p.165-173, 2000.

EC 1646/2004 -Procedure for the establishment of maximum residue limits of veterinary medicinal products in foodstuffs of animal origin. In: Council Regulation (EEC) No 2377/90, Annex 1. Official Journal of the European Union. L 296, 2004. Disponível em: http://ec.europa.eu/health//sites/health/fi les/files/mrl/regpdf/2004_09_21-1646corrigendum_en.pdf. Acessado em 05.03.2017

\section{EMA. EUROPEAN MEDICINES} AGENCY. EMA/MRL/915/04-

FINAL. 2004. Disponível em: http://www.ema.europa.eu/ema. Acessado em 05.03.2017.

FAO/WHO, CODEX ALIMENTARIUS. Toxicological evaluation of certain veterinary drug residues in food.Joint $\mathrm{FAO} / \mathrm{WHO}$ Expert Committee on Food Additives. Codex Alimentarius Comission. 1993.

FAO/WHO, COMITÉ MIXTO. Evaluación de ciertos residuos farmacos de uso veterinario en los alimentos. $34^{\circ}$ Informe del Comité Mixto FAO/WHO de Expertos en Aditivos Alimentarios. 1989. 72p.

FLAJS,V.C.; GRABNAR, I.; ERZEN, N.K.; MARC, I.; POZGAN, U.; GOMBAC, M.; KOLAR, L.;

POGACNIK, M. Pharmacokinetics of doramectin in lactating dairy sheep and suckling lambs. Analytica Chimica Acta,v. 529, p. 353-359, 2005.

HAENLEIN, G. F. W. Goat milk in human nutricion. Smal Ruminant Research, v. 51, n. 2, p. 155-163, 2004. INMETRO - INSTITUTO NACIONAL DE METROLOGIA, NORMALIZAÇÃO E QUALIDADE INDUSTRIAL. DOQ-CGCRE-008:

Orientações sobre validação de métodos analíticos. Revisão 03, 2010. 20p. disponível em: http://www.Inmetro.gov.br/Sidoq/Arqui vos. Acessado em 05.03.2017. 
LANUSSE, C.E.; ALVAREZ, L.I.; LIFSCHITZ, A.L. Princípios farmacológicos da terapia antihelmíntica. In: CAVALCANTE, A.C.R.; VIEIRA, L.S.; CHAGAS, A.C.S.; MOLENTO, M.B. (Eds). Doenças parasitárias de caprinos e ovinos: epidemiologia e controle. Brasília, DF: Embrapa Informação tecnológica, p.549-603, 2009.

MARQUES, M.P.; TAKAYANGUI, O.M.; LANCHOTE, V.L. Albendazole metabolismo in patients with neurocysticercosis: antipyrine as a multifunctional marker drug of cytochrome P450. Brazilian Journal of Medical and Biological Research, v.35, n.2, 2002.

MORENO, L.; IMPERIALE, F.; MOTTIER, L. ALVAREZ, L.; LANUSSE, C. Comparison of milk residue profiles after oral and subcutaneous administration of benzimidazole anthelmintics to dairy cows. Analytica Chimica Acta, v. 536, p. 91-99, 2005.

PARK, Y.W.; JUÁREZ M.; RAMOS M.; HAENLEIN, G.F.W. Physicochemical characteristics of goat and sheep milk. Small Ruminant

Research, v. 68, p. 88-113, 2007.

POLLMEIER, M., MAIER, S., MORIARTY, K., DEMONTIGNY, P. High-performance liquid chromatographic assay for the determination of a semisynthetic avermectin analog (eprinomectin) in bovine milk at parts per billion levelsmethod development and validation. Journal of Chromatography B, v. 772, p. 99-105, 2002.

RIBEIRO, E. L. A.; RIBEIRO, H. J. S. S. Uso nutricional e terapêutico do leite de cabra.Semina: Ciências Agrárias, v. 22, p. 229-235, 2001.

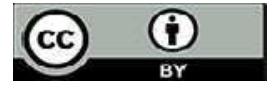

SOUZA, S.V.C. de; LIMA, J.A.; TEODORO, J. C.; JUNQUEIRA, R. G.Validação intralaboratorial de método quantitativo para determinação múltipla de resíduos de avermectinas em leite bovino por cromatografia líquida de alta eficiência com detecção de fluorescência.Ciência e Tecnologia de Alimentos, v.27, n.4, p.823-836, 2007.

TURNIPSEED, S. B.; ROYBAL, J. E.; ANDERSEN, W. C.; KUCK, L. R..

Analysis of avermectin and moxidectin residues in milk by liquid chromatography-tandem mass spectrometry using an atmospheric pressure chemical ionization/atmospheric pressure photoionization source. Analytica Chimica Acta,v. 529, p. 59-165, 2005.

WALDIA, A.; GUPTA, S.; ISSARANI, R.; NAGORI, B.P. Validated liquid chromatographic method for simultaneous estimation of albendazole and ivermectin in tablet dosage form.

Indian Journal of Chemical

Technology, v. 15, p. 617-620, 2008.

WHELAN, M.; KINSELLA, B.; FUREY, A.; MOLONEY, M.; CANTWELL, H.; LEHOTAY, S.J.; DANAHER, M.Determination of anthelmintic drug residues in milk using ultra high performance liquid chromatography-tandem mass spectrometry with rapid polarity switching. Journal of Chromatography A, v.1217, n.27, p.4612-4622, 2010.

XI, X.; YICHUN, D.; PENGJIE, L.; XIA, W.; XIAOWEI, L.; SHUANGYANG, D.; JIANZHONG, S. Determination of benzimidazole residues in bovine milk by ultra-high performance liquid chromatographytandem mass spectrometry. Journal of Chromatography B, v. 878, p. 31743180, 2010. 